\title{
Values Education in 4th Grade Social Science Courses from the Perspectives of Teachers
}

\author{
Mehmet Turan $^{1}$, Eyüp Bozkurt ${ }^{1}$ \\ ${ }^{1}$ Frrat University Faculty of Education Department of Basic Education \\ Correspondence: Eyüp Bozkurt, Frrat University Faculty of Education Department of Basic Education, Turkey.
}

Received: October 8, 2017

Accepted: October 30, 2017

Online Published: November 2, 2017

doi:10.11114/jets.v5i12.2686

URL: https://doi.org/10.11114/jets.v5i12.2686

\begin{abstract}
In today's changing and developing world, the most important elements that enable people to live together in society are values. The education of such values start in the family and the social environment that they are in, from the moment a person is born and do continue in school as the child starts to study. Schools teach values to their students through the programs they practice. One of the most important courses that these values are taught is the social sciences. Social sciences, which is formed to prepare the students for social life is also one of the fundamental courses for the education of values. This study was carried out in order to review the values taught in the 4th grade social science course program, from the vantage point of the teachers. In order to realize this, the achievements in the program were determined and a survey form was created. The study is in a screening model and is descriptive. The study group of the study is composed of 199 classroom teachers working in the province of Elazığ in the academic year of 2016-2017. The data obtained from the research is analyzed using "arithmetic mean" "percentage" and "frequency"; The degree of influence of teacher opinions on variables based on demographic data was also tested using independent $t$ test. According to the results of the research, teachers think that levels of most of the values taught in social sciences course fit the level of understanding of the students. Again, the vast majority of the teachers participated reported that they face a small amount of problems during the teaching of these values to student.
\end{abstract}

Keywords: teaching of values, the education of social sciences and values, acquirements in the education of values

\section{Introduction}

Values are concepts that enable people to have their own place in a society and to live in peace with this society. "If the values are influential on the existence or absence of a community, then the importance of education and teaching of values emerge spontaneously" (Şen, 2007: 15). Values also ensure the formation of a personality and they allow a person to be a part of a society with this personality. "Values indicate to the individuals constituting the society what is important, what is to be preferred, in short, how to live" (Akbaş, 2008: 10). According to Rokeach, (1979), values are beliefs within and beyond national boundaries and cultural contexts that shape our lives and are influential in our core actions. Individuals who know how to live in a society are more peaceful and happier. Because of the values they have, people can keep up with the functioning of the society and can become good people. "Values are the insights that cause and judge behavior" (Genç and Eryaman, 2008: 90). Teaching of values is a process that begins with birth and continues until death. Values education includes everything that affects children's decisions and attitudes (Ulavere \& Veisson, 2015: 111). The education of such values start in the family and the social environment that they are in, from the moment a person is born and do continue in school as the child starts to study. The schools that take over the values education from the families as children start school try to continue the values education through different activities and courses. "The values that individuals possess can only be developed in life, because they are not innate characteristics" (Gömleksiz and Cüro, 2011: 99). The most important duty for the upbringing of a child falls on to the shoulders of the schools.

"At the point where the values are educated, important tasks fall on to our education system and the schools that are the practitioners in this field" (Aladağ, 2012: 126). Schools can pass on the values to the students through the educational activities they carry out and they can ensure that the students grow up in collective cohesion. Because schools can influence the values, habits and social behavior of the new generations (Ekşi, 2003: 81). Thanks to the schools which also are social environments, children can face the outside world, can engage in cultural exchanges and interact with other individuals in the school. "Values are central to both theories of education and the practical activities of schools in 
two ways" (Halstead, 1996: 3). Families, teachers, and other people who pay attention to personality development try to shape the future of young people and want them to grow up with the best values internalized (Baydar, 2009: 21). A student who starts primary school makes school and teacher a top priority and accepts the teacher as a role model. "In the process of socialization, the individual does not just learn the values and norms of the society but also internalizes them" (Altunay, 2015: 415). Because of this, schools bring together all the elements and try to succeed in the education of values. "School climate is based on patterns of people's experiences of school life and reflects norms, goals, values, interpersonal relationships, teaching and learning practices, and organizational structures" (Cohen, Mccabe, Michelli and Pickeral, 2009:182). One of the most important of these elements are the teachers. "Teachers should strive for the highest level of teaching and development, taking into account the social and cultural differences of pupils, their work and their impressions" (Yilmaz, 2009: 112). Teachers are carry out the values education with behaviors that they do or don't in the classroom. Children are more influenced by the characteristics of the teacher that they admire the most (Halstead and Taylor, 2000:178). For this reason, teachers should be good role models for the students and they should endear themselves. In order to establish a society where individuals have various values, education of such values should be systematically planned and implemented in detail (Deveci, 2015: 112). As teachers are planners of educational activities, they have to plan the value education activities in detail and prepare the students for a productive environment at a high level.

As in all other areas of education, there are many changes in the planning, implementation and evaluation of the values education (Paleeri, 2015: 7). These changes enable teachers and schools to conduct value education more effectively and permanently. Many changes made it possible for teachers to benefit from the content and structure of many courses while teaching values. One of the most important of these courses is the social sciences course. Lessons such as life sciences and social sciences play important roles in preparing students for real life, as they are the primary courses for teaching values. After the curriculum change made in 2005, social science course program has been given 22 values for teaching and these values were also included in the achievements of this course. With the changes that are made, values are included in the social sciences course program as achievements and the education of the values are thus realized. Values education is more successful when it is planned within the framework of a specific program, and this also makes such learning permanent. The values that are included in the social sciences course program are important in this respect. There are 17 achievement programs for the 22 values in the social sciences course program. With these achievements, teachers are trying to realize the education of values. The appropriateness of these achievements in the program with the level of students will significantly affect the success of the education made within the scope of the social sciences course. A student experiencing problems in this course will have a hard time internalizing the values that are tried to be transferred.

\subsection{Purpose of the Study}

This research was carried out in order to examine the achievements regarding the values taught in the 4th grade social sciences course program, from the vantage point of the teachers. For this purpose, the achievements related to the values education in the 4th grade social sciences course program were examined and evaluated through the opinions of the teachers. The following objectives have been sought for the realization of the purpose.

- Do the teachers participated in the study find the achievements of values taught in the 4th grade social sciences course program suitable for the level of students?

- On what level do the teachers who participated in the study have problems while teaching the values in the 4th grade social sciences course program?

- According to the gender variable, is there any difference in the teacher opinions who participated in the study regarding the suitability to student level of the educational gains of the teaching of values taught in the 4th grade social sciences course program?

- According to the gender variable, is there any difference in the teacher opinions who participated in the study regarding the problems faced during the teaching of values for the 4 th grade social sciences course program?

- According to the "place of assignment" variable, is there any difference in the teacher opinions who participated in the study regarding the suitability to student level of the educational gains of the teaching of values taught in the 4th grade social sciences course program?

- According to the "place of assignment" variable, is there any difference in the teacher opinions who participated in the study regarding the problems faced during the teaching of values for the 4th grade social sciences course program?

\subsection{Problem Status}

This research tried to find answers to the following questions: 
a) What are the compatibility of the achievements to the students' level for the teaching of values in the primary school 4th grade social sciences course program?

b) What is the rate of problems faced in gaining these achievements to the students in the $4^{\text {th }}$ grade Social Sciences course program?

\section{Method}

\subsection{Research Model}

This research is a descriptive screening study. "The research that consists of the collection of data in order to determine the specific characters of a group is called screening" (Büyüköztürk, Çakmak, Akgün, Karadeniz and Demirci, 2009: 16). "Screening models are research approaches that aim to describe a past or current situation as in the way they exist" (Ersoy, 2013: 362).

\subsection{Study Group}

The study group of the research is composed of 199 classroom teachers working in the province of Elaziğ in the academic year of 2016-2017.

Table.1. Personal info regarding the study group

\begin{tabular}{|c|c|c|c|}
\hline & & Frequency & $\begin{array}{l}\text { Percentage } \\
(\%)\end{array}$ \\
\hline \multirow[t]{3}{*}{ Gender } & Female & 83 & 42.80 \\
\hline & Male & 111 & 57.20 \\
\hline & Academy- Education institute & 33 & 17.30 \\
\hline \multirow[t]{5}{*}{ Graduated school } & $\begin{array}{l}\text { Faculty of } \\
\text { (Bachelor's) }\end{array}$ & 115 & 60.20 \\
\hline & $\begin{array}{l}\text { Other Bachelor's degree } \\
\text { program }\end{array}$ & 43 & 22.50 \\
\hline & $1-5$ years & 5 & 2.50 \\
\hline & $6-10$ years & 15 & 7.80 \\
\hline & $11-15$ years & 32 & 16.50 \\
\hline \multirow{2}{*}{$\begin{array}{l}\text { Occupational } \\
\text { Seniority }\end{array}$} & $16-20$ years & 59 & 30.40 \\
\hline & 21 or more years & 83 & 42.80 \\
\hline \multirow[t]{3}{*}{ Assigned location } & Village- District center & 28 & 14.90 \\
\hline & Province & 160 & 85.10 \\
\hline & 20 or less & 29 & 15.30 \\
\hline \multirow[t]{2}{*}{ Classroom population } & $21-30$ & 100 & 52.60 \\
\hline & $31-40$ & 61 & 32.10 \\
\hline
\end{tabular}

\subsection{Data Collection and Analysis}

Data was obtained through the survey form prepared by the researchers. Survey form was prepared after examining the 4th grade Social Sciences course program, taking into account the achievements in terms of values in the program. The questionnaire consists of 3 parts in total. In the first part of the questionnaire, demographic data are present. Opinions were compared based on these demographic data. In the second part of the survey, there are 17 items on which the educative achievements of values are included. In the second part of the survey, it was aimed to determine the appropriateness of the gains related to value education to student level. In the third part of the questionnaire, there are 17 items on which the educative achievements of values are included. In the third part, it was aimed to determine the problems faced by the teachers while they are trying to gain the achievements of value education to the students. The survey used a five-point likert scale and the evaluation was based on this. SPSS statistical package program was used for the analysis of the data. The data obtained from the research was resolved using "arithmetic mean", "percentage" and "frequency" for analysis; the degree of influence of teacher opinions on variables based on demographic data was tested by independent $\mathrm{t}$ test.

\section{Findings and Comments}

In this section, the findings of the research results are presented and interpreted in tabular form. 


\subsection{Findings and Comments of the Teachers Participated in the Study Regarding the Suitability of the Achievements of the Value Education Provided in the 4th Grade Social Sciences Course Program to the Level of the Students}

Table 2. Results obtained from the findings and comments of the teachers participated in the study regarding the suitability of the achievements of the value education provided in the 4th grade social sciences course program to the level of the students

\begin{tabular}{|c|c|c|c|c|c|c|c|c|}
\hline & $\begin{array}{l}\text { Appropriateness of the achievements of the value education } \\
\text { provided in the 4th grade social sciences course program to the } \\
\text { level of the students }\end{array}$ & 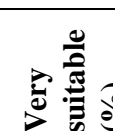 & 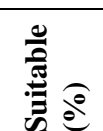 & 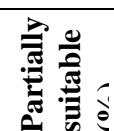 & 之艺 & $\vec{z}$ & $\overline{\mathrm{X}}$ & SS \\
\hline 1 & Respects the feelings and thoughts of others. & 24.20 & 53.00 & 22.20 & .50 & - & 4.01 & .69 \\
\hline 2 & $\begin{array}{l}\text { Recognizes the things that reflect the national culture of his/her } \\
\text { family and surroundings. }\end{array}$ & 19.30 & 57.40 & 22.30 & 1.00 & - & 3.94 & .67 \\
\hline 3 & $\begin{array}{l}\text { Builds the family history by using the oral history method and based } \\
\text { on the objects. }\end{array}$ & 12.20 & 37.60 & 41.10 & 8.60 & .50 & 3.52 & .83 \\
\hline 4 & $\begin{array}{l}\text { Describes his/her immediate surroundings and Turkey during the } \\
\text { National Struggle starting off the actual events and visual materials. }\end{array}$ & 15.20 & 46.00 & 35.90 & 2.50 & .50 & 3.72 & .76 \\
\hline 5 & Can distinguish the natural and human elements around. & 21.90 & 53.60 & 22.40 & 2.00 & - & 3.95 & .72 \\
\hline 6 & $\begin{array}{l}\text { Evaluates the products to be purchased according to the specified } \\
\text { standards }\end{array}$ & 17.30 & 42.30 & 28.60 & 11.70 & - & 3.65 & .90 \\
\hline 7 & $\begin{array}{l}\text { Compares the past and present, taking into account the changes that } \\
\text { technological products initiated in our lives and surroundings. }\end{array}$ & 19.20 & 47.00 & 30.30 & 3.00 & .50 & 3.81 & .79 \\
\hline 8 & $\begin{array}{l}\text { Can design his/her own products initiated by the requirements } \\
\text { around. }\end{array}$ & 10.90 & 33.20 & 42.50 & 11.90 & 1.60 & 3.39 & .89 \\
\hline 9 & Can use technological products without harming others and nature. & 13.20 & 37.60 & 40.10 & 8.10 & 1.00 & 3.53 & .86 \\
\hline 10 & $\begin{array}{l}\text { Recognizes the social organizations, the official institutions and } \\
\text { groups that people form within a certain purpose. }\end{array}$ & 10.60 & 39.40 & 40.90 & 8.60 & .50 & 3.51 & .81 \\
\hline 11 & $\begin{array}{l}\text { Associates group organizations and social organizations with the } \\
\text { main social problems or needs in the environment by using prior } \\
\text { knowledge and experience. }\end{array}$ & 7.10 & 38.10 & 42.60 & 11.70 & .50 & 3.39 & .80 \\
\hline 12 & $\begin{array}{l}\text { Can give examples for the interaction between him/herself and the } \\
\text { surrounding groups of institutions and social organizations. }\end{array}$ & 11.30 & 36.60 & 39.20 & 11.30 & 1.50 & 3.44 & .89 \\
\hline 13 & $\begin{array}{l}\text { Decides on the social and educational activities he/she will attend in } \\
\text { her school and in his/her immediate surroundings. }\end{array}$ & 14.70 & 47.70 & 29.40 & 7.10 & 1.00 & 3.68 & .84 \\
\hline 14 & Recognizes the local government units where he/she lives. & 13.80 & 42.90 & 36.20 & 6.10 & 1.00 & 3.62 & .83 \\
\hline 15 & $\begin{array}{l}\text { Can relate national sovereignty with the opening of the Grand } \\
\text { National Assembly. }\end{array}$ & 19.30 & 50.80 & 25.40 & 4.60 & - & 3.84 & .78 \\
\hline 16 & Can compare his/her daily life with his/her peers in another society. & 14.70 & 46.20 & 34.00 & 5.10 & - & 3.70 & .77 \\
\hline 17 & $\begin{array}{l}\text { Can infer regarding the daily lives of various societies utilizing } \\
\text { visual materials }\end{array}$ & 14.90 & 49.70 & 29.70 & 5.10 & .50 & 3.73 & .79 \\
\hline
\end{tabular}

When we look at table 2, we can see that the teachers participating in the survey have rated the following achievements of the value education in the 4th grade social sciences course program "suitable" with the respective ratios in terms of suitability for the levels of the students. "Respects the feelings and thoughts of others " $(\bar{X}=4.01)$, "Recognizes the things that reflect the national culture of his/her family and surroundings" ( $\bar{X}=3.94)$, "Builds the family history by using the oral history method and based on the objects" $(\overline{\mathrm{X}}=3.52)$, "Describes his/her immediate surroundings and Turkey during the National Struggle starting off the actual events and visual materials" ( $\bar{X}=3.72$ ), "Can distinguish the natural and human elements around" ( $\overline{\mathrm{X}}=3.95)$, "Evaluates the products to be purchased according to the specified standards" ( $\overline{\mathrm{X}}=3.65)$, "Compares the past and present, taking into account the changes that technological products initiated in our lives and surroundings" ( $\overline{\mathrm{X}}=3.81)$, "Can use technological products without harming others and nature" $(\bar{X}=3.53)$, "Recognizes the social organizations, the official institutions and groups that people form within a certain purpose" ( $\overline{\mathrm{X}}=3.51)$, "Can give examples for the interaction between him/herself and the surrounding groups of institutions and social organizations" ( $\mathrm{X}=3.44)$, "Decides on the social and educational activities he/she will attend in her school and in his/her immediate surroundings" $(\bar{X}=3.68)$, "Recognizes the local government units where he/she lives" ( $\bar{X}=3.62)$, "Can relate national sovereignty with the opening of the Grand National Assembly " ( $\bar{X}=3.84)$, "Can compare his/her daily life with his/her peers in another society" $(\bar{X}=3.70)$, "Can infer regarding the daily lives of various societies utilizing visual materials" ( $\overline{\mathrm{X}}=3.73)$.

Again in table 2, it is possible to see that the teachers participating in the survey have rated the following achievements of the value education in the 4th grade social sciences course program "partially suitable" with the respective ratios in terms of suitability for the levels of the students. "Can design his/her own products initiated by the requirements around" 
$(\bar{X}=3.39)$, "Associates group organizations and social organizations with the main social problems or needs in the environment by using prior knowledge and experience" ( $\overline{\mathrm{X}}=3.39)$.

3.2 Findings and Comments of the Teachers Participated in the Study Regarding the Problems Faced during the Value Education Provided in the 4th Grade Social Sciences Course Program

Table 3. Results obtained from the findings and comments of the teachers participated in the study regarding the problems faced during the value education provided in the 4 th grade social sciences course program

\begin{tabular}{|c|c|c|c|c|c|c|c|c|}
\hline & $\begin{array}{l}\text { The ratio of problems faced during the teaching of values } \\
\text { provided in the } 4 \text { th grade social sciences course program }\end{array}$ & 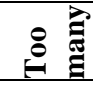 & $\sum_{\Sigma}^{\pi}$ & Eั & 总 & $\hat{z}$ & $\bar{X}$ & ss \\
\hline 1 & Respects the feelings and thoughts of others. & 6.20 & 11.90 & 37.50 & 39.20 & 5.10 & 2.75 & .95 \\
\hline 2 & $\begin{array}{l}\text { Recognizes the things that reflect the national culture of his/her } \\
\text { family and surroundings. }\end{array}$ & 2.90 & 17.20 & 35.10 & 37.40 & 7.50 & 2.70 & .93 \\
\hline 3 & $\begin{array}{l}\text { Builds the family history by using the oral history method and } \\
\text { based on the objects. }\end{array}$ & 2.90 & 19.20 & 43.00 & 28.50 & 6.40 & 2.83 & .90 \\
\hline 4 & $\begin{array}{l}\text { Describes his/her immediate surroundings and Turkey during the } \\
\text { National Struggle starting off the actual events and visual } \\
\text { materials. }\end{array}$ & 3.40 & 13.70 & 41.10 & 33.10 & 8.60 & 2.70 & .93 \\
\hline 5 & Can distinguish the natural and human elements around. & 4.00 & 12.10 & 30.10 & 40.50 & 13.30 & 2.53 & 1.00 \\
\hline 6 & es the products to be purchased according to the specified & 2.30 & 12.70 & 39.30 & 35.80 & 9.80 & 2.61 & .91 \\
\hline 7 & $\begin{array}{l}\text { Compares the past and present, taking into account the changes } \\
\text { that technological products initiated in our lives and surroundings. }\end{array}$ & 3.40 & 12.10 & 35.60 & 38.50 & 10.30 & 2.59 & .94 \\
\hline 8 & $\begin{array}{l}\text { Can design his/her own products initiated by the requirements } \\
\text { around. }\end{array}$ & 5.20 & 14.50 & 42.40 & 32.60 & 5.20 & 2.81 & .92 \\
\hline 9 & Can use technological products without harming others and nature. & 5.20 & 14.90 & 30.50 & 42.50 & 6.90 & 2.68 & .98 \\
\hline 10 & $\begin{array}{l}\text { Recognizes the social organ } \\
\text { groups that people form withi }\end{array}$ & 4.00 & 12.60 & 48.30 & 29.90 & 5.20 & 2.80 & .87 \\
\hline 11 & $\begin{array}{l}\text { izations and social organizations with the } \\
\text { r needs in the environment by using prior } \\
\text { cee. }\end{array}$ & 2.30 & 14.90 & 46.00 & 31.60 & 5.20 & 2.77 & .84 \\
\hline 12 & $\begin{array}{l}\text { Can give examples for the interaction between him/herself and the } \\
\text { surrounding groups of institutions and social organizations. }\end{array}$ & 3.40 & 9.10 & 53.70 & 27.40 & 6.30 & 2.76 & .83 \\
\hline 13 & $\begin{array}{l}\text { Decides on the social and educational activities he/she will attend } \\
\text { in her school and in his/her immediate surroundings. }\end{array}$ & 6.30 & 13.80 & 37.40 & 34.50 & 8.00 & 2.75 & 1.00 \\
\hline 14 & Recognizes the local government units where he/she lives. & 5.80 & 14.50 & 42.80 & 29.50 & 7.50 & 2.81 & .97 \\
\hline 15 & $\begin{array}{l}\text { Can relate national sovereignty with the opening of the Grand } \\
\text { National Assembly. }\end{array}$ & 4.60 & 12.70 & 33.50 & 41.60 & 7.50 & 2.65 & .95 \\
\hline 16 & $\begin{array}{l}\text { Can compare his/her daily life with his/her peers in another } \\
\text { society. }\end{array}$ & 4.00 & 12.00 & 39.40 & 33.70 & 10.90 & 2.64 & .96 \\
\hline 17 & $\begin{array}{l}\text { Can infer regarding the daily lives of various societies utilizing } \\
\text { visual materials. }\end{array}$ & 3.40 & 12.60 & 41.70 & 30.90 & 11.40 & 2.65 & .95 \\
\hline
\end{tabular}

When we look at table 3, we can see that the teachers participating in the survey have mentioned a moderate amount of problems for the following achievements of the value education in the 4th grade social sciences course program with the respective ratios. "Respects the feelings and thoughts of others" $(\bar{X}=2.75)$, "Recognizes the things that reflect the national culture of his/her family and surroundings" ( $\overline{\mathrm{X}}=2.70)$, "Builds the family history by using the oral history method and based on the objects" ( $\overline{\mathrm{X}}=2.83)$, "Describes his/her immediate surroundings and Turkey during the National Struggle starting off the actual events and visual materials" $(\overline{\mathrm{X}}=2.70)$, "Evaluates the products to be purchased according to the specified standards" ( $\overline{\mathrm{X}}=2.61)$, Can design his/her own products initiated by the requirements around" ( $\bar{X}=2.81)$, "Can use technological products without harming others and nature" ( $\bar{X}=2.68)$, "Recognizes the social organizations, the official institutions and groups that people form within a certain purpose” ( $\bar{X}=2.80)$, ““'Associates group organizations and social organizations with the main social problems or needs in the environment by using prior knowledge and experience" ( $\overline{\mathrm{X}}=2.77$ ), "Can give examples for the interaction between him/herself and the surrounding groups of institutions and social organizations" $(\bar{X}=2.76)$, "Decides on the social and educational activities he/she will attend in her school and in his/her immediate surroundings" ( $\bar{X}=2.75)$, "Recognizes the local government units where he/she lives" ( $\bar{X}=2.81$ ), "Can relate national sovereignty with the opening of the Grand National Assembly " $(\bar{X}=2.65)$, "Can compare his/her daily life with his/her peers in another society" $(\bar{X}=2.64)$, "Can infer regarding the daily lives of various societies utilizing visual materials" ( $\mathrm{X}=2.65)$.

Also in table 3, teachers participating in the survey have mentioned less amount of problems for the following achievements of the value education in the 4th grade social sciences course program with the respective ratios, "Can 
distinguish the natural and human elements around" ( $\overline{\mathrm{X}}=2.53)$, "Compares the past and present, taking into account the changes that technological products initiated in our lives and surroundings" ( $\overline{\mathrm{X}}=2.59)$.

3.3 Results and Comments of the T Test Made on Gender Variable Regarding the Teachers' Participating in the Study Finding the Achievements Suitable for the Student Level, of the $4^{\text {th }}$ Grade Social Science Course Program

As a result of the analysis made on the gender variable regarding the teachers' participating in the study finding the achievements suitable for the student level, of the 4th grade social science course program, no statistically significant difference was found between the items.

3.4 Results and Comments of the T Test Made on the Gender Variable Regarding Teachers' Participating in the Study Having Problems While Presenting the Value Education to the Students of the $4^{\text {th }}$ Grade Social Science Course Program

As a result of the analysis made on the gender variable regarding the teachers' participating in the study having problems while presenting the value education to the students, of the 4th grade social science course program, no statistically significant difference was found between the items

3.5 Results and Comments of the T Test Made on "the Place of Assignment" Variable Regarding the Teachers' Participating in the Study Finding the Achievements Suitable for the Student Level, of the $4^{\text {th }}$ Grade Social Science Course Program

As a result of the analysis made on the gender variable regarding the teachers' participating in the study finding the achievements suitable for the student level, of the 4th grade social science course program, differences have been found in 7 achievements and these were presented in table 4 .

Table 4. Results of the t test made on "the place of assignment" variable regarding the teachers' participating in the study finding the achievements suitable for the student level, of the 4th grade social science course program

\begin{tabular}{|c|c|c|c|c|c|c|c|c|}
\hline \multirow{2}{*}{$\mathrm{MN}$} & \multicolumn{3}{|c|}{ Village - district center } & \multicolumn{3}{|c|}{ Province } & \multirow[b]{2}{*}{$\mathrm{t}$} & \multirow[b]{2}{*}{$\mathrm{p}$} \\
\hline & $\mathrm{n}$ & $\overline{\mathrm{X}}$ & ss & $\mathrm{n}$ & $\overline{\mathrm{X}}$ & ss & & \\
\hline 1 & 28 & 3.67 & .54 & 160 & 4.04 & .70 & -2.61 & .01 \\
\hline 2 & 28 & 3.46 & .57 & 159 & 4.01 & .84 & -4.22 & .00 \\
\hline 3 & 28 & 3.17 & .72 & 159 & 3.57 & .84 & -2.35 & .01 \\
\hline 7 & 28 & 3.50 & .57 & 160 & 3.83 & .81 & -2.07 & .04 \\
\hline 9 & 28 & 3.10 & .83 & 159 & 3.60 & .84 & -2.88 & .04 \\
\hline 10 & 28 & 3.14 & .70 & 160 & 3.54 & .79 & -2.48 & .01 \\
\hline 12 & 28 & 3.14 & .70 & 156 & 3.49 & .88 & -1.98 & .04 \\
\hline
\end{tabular}

$\mathrm{P}<.05$

1. 2. 3. 7. 9. 10th and 12 th items which had statistically significant differences in the results of $t$ test made according to the assignment place variable are interpreted in this section. When table 4 is examined, the first item which is the achievement of "Respects the feelings and thoughts of others" can be seen to have statistically significant difference among the participants in terms of the "assignment place" variable. [t=-2.61; $\mathrm{p}<.05]$. This achievement is found to be more suitable for student level $(\overline{\mathrm{X}}=4.04)$ by the provincial teachers compared to the ones working in the villages and district centers $(\overline{\mathrm{X}}=3.67)$.

When table 4 is examined, it can be seen that regarding the second item which is "Recognizes the things that reflect the national culture of his/her family and surroundings" there is a statistically significant difference in the result of the analysis made according to the variable of assignment place by the participants in the survey. $[t=--4.22 ; \mathrm{p}<.05]$. This achievement is found to be more suitable for student level by the provincial teachers $(\overline{\mathrm{X}}=4.01)$ compared to the ones working in the villages and district centers $(\overline{\mathrm{X}}=3.46)$.

When table 4 is examined, it can be seen that regarding the third item which is "Builds the family history by using the oral history method and based on the objects" there is a statistically significant difference in the result of the analysis made according to the variable of assignment place by the participants in the survey. [t=-2.35; $p<.05]$. This achievement is found to be more suitable for student level by the provincial teachers $(\overline{\mathrm{X}}=3.57)$ compared to the ones working in the villages and district centers $(\overline{\mathrm{X}}=3.17)$.

When table 4 is examined, it can be seen that regarding the seventh item which is "Compares the past and present, taking into account the changes that technological products initiated in our lives and surroundings" there is a statistically significant difference in the result of the analysis made according to the variable of assignment place by the participants in the survey. $[\mathrm{t}=-2.07 ; \mathrm{p}<.05]$. This achievement is found to be more suitable for student level by the provincial teachers $(\overline{\mathrm{X}}=3.83)$ compared to the ones working in the villages and district centers $(\overline{\mathrm{X}}=3.50)$.

When table 4 is examined, it can be seen that regarding the ninth item which is "Can use technological products without 
harming others and nature" there is a statistically significant difference in the result of the analysis made according to the variable of assignment place by the participants in the survey. [t=-2.88; $\mathrm{p}<.05]$. This achievement is found to be more suitable for student level by the provincial teachers $(\overline{\mathrm{X}}=3.60)$ compared to the ones working in the villages and district centers $(\overline{\mathrm{X}}=3.10)$.

When table 4 is examined, it can be seen that regarding the tenth item which is "Recognizes the social organizations, the official institutions and groups that people form within a certain purpose" there is a statistically significant difference in the result of the analysis made according to the variable of assignment place by the participants in the survey. [t=-2.48; $p<.05]$. This achievement is found to be more suitable for student level by the provincial teachers $(\bar{X}=3.54)$ compared to the ones working in the villages and district centers $(\overline{\mathrm{X}}=3.14)$.

When table 4 is examined, it can be seen that regarding the twelfth item which is "Can give examples for the interaction between him/herself and the surrounding groups of institutions and social organizations" there is a statistically significant difference in the result of the analysis made according to the variable of assignment place by the participants in the survey. [t=-1.98; $\mathrm{p}<.05]$. This achievement is found to be more suitable for student level by the provincial teachers $(\overline{\mathrm{X}}=3.49)$ compared to the ones working in the villages and district centers $(\overline{\mathrm{X}}=3.14)$.

3.6 Results and Comments of the T Test Made on "the Assignment Place" Variable Regarding Teachers' Participating in the Study Having Problems While Presenting the Value Education to the Students of the $4^{\text {th }}$ Grade Social Science Course Program

As a result of the analysis made on the "assignment place" variable regarding the teachers' participating in the study having problems during the teaching of values to the students of the 4th grade social science course program, differences have been found in 2 achievements and these were presented in table 5

Table 5. T test values in terms of the "assignment place" variable regarding the teachers' participating in the study having problems during the teaching of values to the students of the 4th grade social science course program

\begin{tabular}{lllllllll}
\hline \multirow{2}{*}{ MN } & \multicolumn{7}{l}{ Village - district center } & \multicolumn{2}{c}{ Province } & \multirow{2}{*}{$\mathrm{t}$} & \multirow{2}{*}{$\mathrm{p}$} \\
\cline { 2 - 7 } & $\mathrm{n}$ & $\overline{\mathrm{X}}$ & $\mathrm{ss}$ & $\mathrm{n}$ & $\overline{\mathrm{X}}$ & $\mathrm{ss}$ & & \\
\hline 9 & 28 & 3.07 & .85 & 140 & 2.63 & .99 & 2.15 & .03 \\
12 & 28 & 3.10 & .73 & 141 & 2.71 & .83 & 2.29 & .02 \\
\hline
\end{tabular}

$\mathrm{P}<.05$

9. 12th items which had statistically significant differences in the results of $t$ test made according to the assignment place variable are interpreted in this section. When table 5 is examined, the ninth item which is the achievement of "Can use technological products without harming others and nature" can be seen to have statistically significant difference among the participants in terms of the "assignment place" variable. $[t=2.15 ; \mathrm{p}<.05]$. Teachers working in villages district centers seem to have more problems while teaching these achievements to students $(\bar{X}=3.07)$ compared to provincial teachers $(\overline{\mathrm{X}}=2.63)$.

When table 5 is examined, the twelfth item which is the achievement of "Can give examples for the interaction between him/herself and the surrounding groups of institutions and social organizations" can be seen to have statistically significant difference among the participants in terms of the "assignment place" variable. $[t=2.29 ; p<.05]$. Teachers working in villages - district centers seem to have more problems while teaching these achievements to students $(\bar{X}$ $=3.10)$ compared to provincial teachers $(\overline{\mathrm{X}}=2.71)$.

\section{Discussion, Conclusion and Suggestions}

\subsection{Discussion and Conclusion}

Teachers who participated in the study found fifteen achievements were suitable for the student level, and two achievements were partially suitable. In this sense, it can be said that the achievements related to the education of the values included in the 4th grade social studies course curriculum are found suitable to student level by the teachers. It is essential to determine what values you need to teach in the school environment or in the classroom environment by observations, negotiations and scales to be implemented, and then a planned value education can be carried out (Ay, 2014: 20). So these findings obtained present great importance in terms of effective and efficient teaching of values.

Teachers who participated in the study were found to have moderate problems in the teaching of the 15 achievements of values, while they mentioned "few" problems in the two achievements. This resulted in the conclusion that teachers experienced moderate problems when they are teaching the achievements related to the values education in the 4th grade social sciences course program. While this finding is important, it is necessary to provide alternative education situations related to the source and solutions of the problems. In addition, Balc1 and Yelken (2013: 208) found that in their research that teachers generally had moderate difficulty in teaching values. This result is consistent with the findings obtained in this research. 
There was no statistically significant difference in the results of the analysis according to the gender variable regarding the suitability of the achievements to the student level. Again, there was no statistically significant difference in the results of the analysis according to the gender variable as to whether there was a problem in the teaching of the values or not.

As a result of the analysis made according to the assignment place variable regarding the suitability of the achievements of the values to student level from the vantage point of the teachers participating in the research; Teachers working in the province center found to have found the achievements more suitable to the student level compared to the ones working in villages and district centers. In the Village-District environment, it is less likely to see and reflect the national culture in villages and district centers as the local culture would be more prominent.

Again as a result of the analysis made according to the assignment place variable regarding the suitability of the achievements of the values to student level from the vantage point of the teachers participating in the research; the achievements "Builds the family history by using the oral history method and based on the objects" and "Compares the past and present, taking into account the changes that technological products initiated in our lives and surroundings" is found to be more suitable for student level by the provincial teachers compared to the teachers in villages and district centers. It is normal and reasonable for the students who are studying in the village-district environment who see less technological products do not see much change in their lives and environments, compared to the students in provincial centers who witness such changes much more.

Again as a result of the analysis made according to the assignment place variable regarding the suitability of the achievements of the values to student level from the vantage point of the teachers participating in the research; the achievements "Can use technological products without harming others and nature" "Recognizes the social organizations, the official institutions and groups that people form within a certain purpose" and "Can give examples for the interaction between him/herself and the surrounding groups of institutions and social organizations" found to be more suitable for student level by the provincial teachers compared to village and district teachers. The level of use of technological products and the level of social organization and communication with official institutions is low among the students who are studying in village-district environment. Therefore, teachers' more positive perceptions on behalf of students in the city center compared to the ones in villages and districts, in terms of student achievements are both normal and reasonable. No matter how much social activity is in the village-district environment, the use of technological products, the establishment of social organizations and the level of communication with official institutions are never as much as the provincial center.

As a result of the analysis made according to the assignment place variable regarding the problems faced by the teachers while teaching values to students; the achievements "Can use technological products without harming others and nature" and "Can give examples for the interaction between him/herself and the surrounding groups of institutions and social organizations" are found to be more problematic to achieve by the teachers in the villages and district centers compared to the teachers in provincial centers. The use of technological products and the level of establishing a social organization is low among the students in the village-district environment. It is therefore normal for teachers who work in villages and districts to be less challenged while teaching such values for achievements compared to the provincial teachers. In addition, it is normal for the students who are educated in village-district environment to be less familiar with technology use and less habitual and less in contact with social institutions compared to students in provincial centers and it can be said that teachers have problems in teaching these values because of these.

\subsection{Suggestions}

Based on research findings, following suggestions have been develoed to curriculum developers, teachers and researchers as well.

- Program work can be done so that the achievements regarding to values are included in other courses also.

- Achievements can be made more functional and to adapt to student level.

- Achievements can be made clearer and understandable.

- Measures can be taken to ensure that the achievements do not cause problems in rural areas, and they can be modified to be more suitable accordingly.

- Researchers can work to determine achievements that are incompatible with values education.

- Researchers can conduct research on the reasons why the values in the program are not suitable to the student's level of educational attainment.

- Research on the solutions of the problems that the teachers experience while teaching values in the classroom during the social sciences course program can be conducted. 
Note: This study was presented as verbal announcement at the 26th International Congress of Educational Sciences in Antalya Province on May 2017.

\section{References}

Akbaş, O. (2008). An overview of value education trends. Değerler Eğitimi Dergisi, 6(16), 9-27.

Aladağ, S. (2012). The effect of value education approaches on primary school students social science course regarding gaining responsibility on the cognitive level. Türkiye Sosyal Araştırmalar Dergisi, 161(161), 123.

Altunay, A. (2015). New media as a means of socializing. Selçuk Üniversitesi Iletişsim Fakültesi Akademik Dergisi, 9(1), 410-428. https://doi.org/10.18094/si.48539

Ay, S. T. (2014). Teaching of values in schools. R. Turan and K. Ulusoy (Ed.) Education of values in different aspects inside, (s: 18-37). Ankara: Pegem.

Balc1, F. A., \& Yelken, T. Y. (2013). Teacher opinions regarding the values and application of value education in the social sciences course in primary schools. Ahi Evran University Kirşehir Faculty of Education Magazine, 14(1).

Baydar, P. (2009). The level of achievement of the values determined in the fifth grade social sciences program and evaluation of the problems experienced in this process. Master Thesis. Cukurova University Social Sciences Institute. Adana.

Büyükzötürk, Ş., Çakmak, E. K., Akgün, Ö. E., Karadeniz, Ş., \& Demirel, F. (2009). Scientific research methods. Ankara: Pegem

Cohen, J., McCabe, L., Michelli, N. M., \& Pickeral, T. (2009). School climate: Research, policy, practice, and teacher education. Teachers college record, 111(1), 180-213.

Deveci, H. (2015). Value education through distance learning: opinions of students who already completed value education. Turkish Online Journal of Distance Education, 16(1). https://doi.org/10.17718/tojde.89079

Ekşi, H. (2003). An approach to gaining basic human values: Character education programs. Değerler Eğitimi Dergisi. $1(1), 79-96$.

Ersoy, E. (2013). Quantitative research methods. S. Baştürk (Ed.). Scientific research methods(s: 339- 374). inside. Ankara: Vize.

Genç, S. Z., \& Eryaman, M. Y. (2008). Changing values and the new educational paradigm. Sosyal Bilimler Dergisi, 9(1), 89-102. https://doi.org/10.1080/713657146

Gömleksiz, M. N., \& Cüro. E. (2011). Assessment of student attitudes about the values in Social Sciences course curriculum. Uluslararası İnsan Bilimleri Dergisi, 8(1), 95-134.

Halstead, J. M. (1996). Values and values education in schools. Values in education and education in values, 3-14.

Halstead, J. M., \& Taylor, J. M. (2000). Learning and teaching about values: a review of recent research. Cambridge Journal of Education, 30(2), 169-202.

Paleeri, S. (2014). Setting objectives of value education in constructivist approach in the light of revised blooms taxonomy (RBT). i-Manager's Journal on School Educational Technology, 10(3), 7.

Rokeach, M. (1979). Understanding human values: Individual and societal. London: Collier MacMillan

Şen, Ü. (2007). A Study on Teaching Values in Turkish Education Through 100 Basic Works Recommended by the Ministry of National Education in 2005. Master Thesis, Gazi University, Ankara.

Ülavere, P., \& Veisson. M. (2015). Values and values education in Estonian preschool child care institutions. Journal of Teacher Education for Sustainability, 17(2), 108-124. https://doi.org/10.1515/jtes-2015-0014

Yılmaz, E. (2009). Examination of teachers' value preferences in terms of some variables. Değerler Eğitimi Dergisi, 7(17), 109-128.

\section{Copyrights}

Copyright for this article is retained by the author(s), with first publication rights granted to the journal.

This is an open-access article distributed under the terms and conditions of the Creative Commons Attribution license which permits unrestricted use, distribution, and reproduction in any medium, provided the original work is properly cited. 